\title{
Анализ полупроводниковых слоев AIN на подложке сапфира (0001) методом спектроскопии поверхностных поляритонов
}

\author{
Д.С. Милахин ${ }^{1}$, Т.В. Малин ${ }^{1}$, В.Г. Мансуров ${ }^{1}$, К.С. Журавлев ${ }^{1,2}$ \\ ${ }^{1}$ Институт физики полупроводников им. А.В. Ржанова СО РАН, Новосибирск, \\ 630090, пр. Ак. Лаврентьева, 13 \\ ${ }^{2}$ Новосибирский государственный университет, Новосибирск, 630090, ул. Пирогова, 2 \\ тел: +7 (383) 330-4475, эл. почта: dmilakhin@isp.nsc.ru
}

DOI 10.34077/RCSP2021-128

После успеха Исаму Акасаки, Хироси Амано и Сюдзи Накамура в получении первого синего светодиода высокой яркости на основе полупроводниковых соединений $\mathrm{A}_{3}$-нитридов на подложке сапфира, данные полупроводники рассматриваются как очень перспективная группа материалов для оптоэлектронных применений, таких как светоизлучающие диоды, лазерные диоды и УФ фотодетекторы. В связи с малой распространённостью и доступностью собственных подложек для эпитаксиального роста $\mathrm{AlN}$, используются инородные подложки сапфира $\left(\mathrm{Al}_{2} \mathrm{O}_{3}\right), \mathrm{Si}$ и $\mathrm{SiC}$. Сапфир является наиболее распространенной подложкой ввиду высокого кристаллического совершенства и низкой стоимости. Однако, из-за рассогласования периодов решеток $\operatorname{AlN}\left(\mathrm{a}_{\mathrm{AlN}}=3,11 \AA\right)$ и подложки $\mathrm{Al}_{2} \mathrm{O}_{3}\left(\mathrm{a}_{\mathrm{Al} 2 \mathrm{O}}=4,76 \AA\right)$, равного $\left(\mathrm{a}_{\mathrm{Al2O}}-\mathrm{a}_{\mathrm{AIN}}\right) / \mathrm{a}_{\mathrm{AIN}}=53,1 \%$, эпитаксиальный рост AIN на сапфире сопровождается формированием поликристаллической структуры [1], в результате чего гетероструктуры получаются низкого кристаллического качества. Для согласования слоев AlN c подложкой $\mathrm{Al}_{2} \mathrm{O}_{3}$ осуществляется процесс нитридизации,

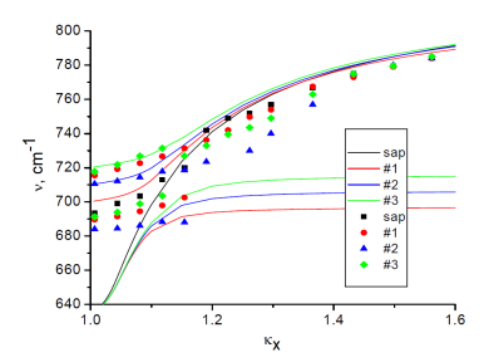

Рис.1. - Дисперсионные кривые исходного и нитридизованного сапфира: \#1 - 300 с при $935^{\circ} \mathrm{C}$, \#2 - 590 с при $935^{\circ} \mathrm{C}$ и \#3 - 590 с при $865^{\circ} \mathrm{C}$. заключающийся в экспонировании нагретой подложки в потоке активного азота. В результате на поверхности подложки формируется тонкий (1-3 MC) зародышевый слой $\mathrm{AlN}$, кристаллическая ячейка которого располагается с поворотом на $30^{\circ}$ относительно кристаллической ячейки $\mathrm{Al}_{2} \mathrm{O}_{3}$, что приводит к снижению эффективного рассогласования параметров решёток $\mathrm{AlN}$ и $\mathrm{Al}_{2} \mathrm{O}_{3}$ до $13 \%$. Поскольку качество всех последующих слоев зависит от условий нитридизации, нельзя переоценить важность этого процесса [1,2]. Структура зародышевых слоев AlN, полученных при разных условиях нитридизации, должна быть тщательно качественно и количественно изучена. Для исследования тонкого зародышевого слоя AlN необходимы очень чувствительные методы. Для характеристики зародышевых и буферных слоев $\mathrm{AlN}$, полученных на подложке $\mathrm{Al}_{2} \mathrm{O}_{3}$ методом аммиачной МЛЭ, были использованы методы инфракрасной (ИК) спектроскопии (ИК отражение и нарушенное полное внутреннее отражение (НПВО)).

Обнаружено, что ИК спектры отражения нитридизованного сапфира практически совпадают со спектрами исходной сапфировой подложки. Спектр отражения буферного слоя AlN отличается от спектра сапфировых подложек наличием характерного минимума частоты $651 \mathrm{~cm}^{-1}$, соответствующего ТО-фононам. В методе НПВО часть падающего ИК излучения проникает в образец, активно взаимодействуя с оптическими фононами и образуя поверхностные поляритоны (ПП), и, в результате, поглощается в характеристических для образца длинах волн. Высокая чувствительность ПП позволяет наблюдать изменение спектров подложки даже после изменения параметров процесса нитридизации. Сравнение спектров НПВО исходных и нитридизованных сапфировых подложек указывает на появление минимума в точке $700 \mathrm{~cm}^{-1}$. При взаимодействии ИК излучения с фононами пленки AIN в области резонансных частот наблюдается расщепление закона дисперсии. Для сапфировых подложек, нитридизованных в разных условиях, расщепление находилось в диапазоне 700-720 cм${ }^{-1}$ ТО-частот.

Авторы выражают благодарность Н.Н. Новиковой и В.А. Яковлеву из Института спектроскопии РАН за проведение измерений методами ИК спектроскопии.

Работа выполнена в рамках государственного задания 0306-2019-00008 «Гетероструктуры на основе материалов $\mathrm{A}_{3} \mathrm{~B}_{5}$ для СВЧ-электроники и СВЧ-фотоэлектроники».

\section{Лumepamypa}

[1] D.S. Milakhin et al. // IEEE Xplore. 2020. Vol.1. P.14-18.

[2] D.S. Milakhin et al. // JTAC. 2018. Vol.133, No.2. P.1099-1107. 